\title{
ALERT W XXI WIEKU. ZMIANY TEORII OCHRONY DZIEŁ DZIEDZICTWA W ZNACZENIU MATERIALNYM, NIEMATERIALNYM I CYFROWYM
}

\section{SZMELTER Iwona ${ }^{1}$}

${ }^{1}$ prof. zw. dr hab. Iwona Szmelter, Wydział Konserwacji-Restauracji Dzieł Sztuki Akademia Sztuk Pięknych w Warszawie https://orcid.org/0000-0002-9557-6509

ABSTRAKT: 'Alert' przedstawia potrzebę rozszerzenia teorii ochrony dziedzictwa kultury w znaczeniu nie tylko materialnym, ale i niematerialnym oraz cyfrowym. Wobec przemian we współczesnym świecie stoimy w obliczu wszechogarniających zmian obszaru dziedzictwa, które modyfikują misję „chronić i przekazywać”. Zastana sytuacja ukazuje nieadekwatność dawnych teorii konserwatorskich i fragmentację doktryn. Autorka przedstawia w czytelnej strukturze możliwe scenariusze rozwiązania kryzysu w teorii i systemie ochrony. Nowe zagadnienia obejmujązarówno teorię konserwacji tradycyjnych dyscyplin przezjej rozszerzone rozpoznanie i dokumentację, jak i innowacyjną ochronę rozszerzonego obszaru dziedzictwa, wraz z paradygmatami współczesnej teorii. Kolejne zagadnienia dotyczą potrzeby reformy istniejących procedur w instytucjach kulturalnych. Uczestnicząc w przełomie kulturalnym nie powinniśmy być ani bierni, ani rewolucyjni, lecz adekwatnie dostosowywać teorię, projekty i prawodawstwo. Aktywna postawa wymaga odpowiedzi na podstawowe pytania: co chronimy w obliczu rozszerzenia obrazu dziedzictwa kultur? Jak dokonać łącznego (holistycznego) zachowania dotychczasowego prymatu kultury materialnej i jednocześnie potrzebnego usankcjonowania ochrony dziedzictwa niematerialnego? Czy w porę dostrzegamy i reagujemy na rosnące znaczenie cyfryzacji objawów sztuki i powstającego jej dziedzictwa? Jak sprowokować optymalne uczestnictwo odbiorców w ochronie dziedzictwa? Odpowiedzi na te pytania okazują się bardzo ważne, bowiem mogą być pomocnym drogowskazem zmian i analizy wartościującej w dwóch uzupełniających si kategoriach: kulturalno-historycznych i społeczno-ekonomicznych, które w rzeczywistości wzajem się przenikają.

SŁOWA KLUCZE: dziedzictwo sztuk wizualnych, teoria konserwacji, analiza wartościująca, paradygmaty współczesnej teorii konserwacji, filary praktyki konserwacji 


\section{Wprowadzenie}

Symptomy zmian cywilizacyjnych wskazują na czas przesilenia dotychczasowych rozwiązań doktrynalnych w teorii ochrony i konserwacji dziedzictwa kultury'1 ${ }^{1}$ W społeczności zajmującej się ochroną dziedzictwa opracowane są zagadnienia ochrony dziedzictwa dawnej sztuki, w tym głównie zabytków nieruchomych, które są unormowane prawnie tak na świecie, jak i w Polsce². Natomiast zagadnienia ochrony dóbr kultury, szerzej rozumianych niż zabytki, są wprawdzie ujęte w Konstytucji, ale nieobecne w procedurach i wytycznych dla instytucji. Bogusław Szmygin argumentował potrzebę rewizji klasycznych zasad konserwatorskich:

Intensywne i szybkie przemiany zachodzace we współczesnym świecie maja znaczacy wplyw na ochronę dziedzictwa. Zmienia się przedmiot ochrony, jej formy oraz sposób ich realizacji. Coraz szersze pojęcie dziedzictwa jest konfrontowane $z$ rosnaca potrzeba przekształceń i modernizacji naszego otoczenia ${ }^{3}$.

Potrzeba ta wymaga zaspokojenia począwszy od generalnego obrazu dziedzictwa, gdyż chroniąc dziedzictwo przywołujemy jego charakter wskazujący na związek kultury i natury. Ta prawda znana prawdopodobnie wszystkim intuicyjnie, podobnie jak prawo naturalne, została potwierdzona w swej ważności Konwencją UNESCO z 1972 roku. Niestety, po upływie półwieku nadal często pozostaje postulatem odległym od realizacji. Celebrujemy rocznicę podpisania Karty Ateńskiej z 1931 roku o niezbędnym związku sztuki z nauką, a także Deklaracji HUB daleko idącej w rozumieniu różnorodności współczesnego dziedzictwa, lecz mimo celebracji mało widocznych w polityce kulturalnej.

\section{Meritum zmian}

Dyskurs zacznijmy od podstawowych pojęć 'dziedzictwa sztuk wizualnych', a także innych cywilizacyjnych dokonań człowieka, które trwają ciągle, czyli od początków istnienia człowieka do umownego ‘dzisiaj. Współcześnie termin sztuki wizualne obejmuje zakres daleko przekraczający po-oświeceniowe podziały dziedzin, jak sztuki piękne, czy sztuki plastyczne, z ich wielowiekową dyskryminacją innych form dziedzictwa ${ }^{4}$. W tej rozległej perspektywie ograniczenie do kultury materialnej byłoby uprzedmiotowieniem dziedzictwa człowieka, które jednak zawsze miało i nadal ma cechy duchowe, niematerialne właściwe człowiekowi. Wystarczyło tylko trzysta

${ }^{1}$ Termin „dziedzictwo kultury” za: Gieysztor A., O dziedzictwie kultury, Towarzystwo Opieki nad Zabytkami, Warszawa 2001.

${ }^{2}$ Zalasińska K., Prawna ochrona zabytków nieruchomych w Polsce, Warszawa 2010.

${ }^{3}$ Szmygin B., Wprowadzenie, [w:]Współczesne Problemy Teorii Konserwatorskiej w Polsce, red. B. Szmygin, Międzynarodowa Rada Ochrony Zabytków ICOMOS, Politechnika Lubelska,Warszawa Lublin 2008, s. 5.

4 Szmelter I., O fenomenie sztuk wizualnych i meandrach ich ochrony, Filozofia i elementy nowej teorii i praktyki konserwacji, Wydawnictwo Naukowe PWN, Warszawa 2020. 
lat antropocentryzmu z po-oświeceniową polityką i rewolucją techniczną, by zapomnieć o różnorodnym charakterze sztuki. Dlaczego?

Przydatnaokazujesiępróbascharakteryzowaniawspółczesnychzmianwidzianychoczamifilozofów i politologów z ostatniego półwiecza. Kategorią opisu kultury w ujęciu postmodernistycznym było pojęcie „płynnej nowoczesności” (liquid modernity w j.ang.) wprowadzone przez Zygmunta Baumana ${ }^{5}$. Ukazanie niestałości struktur kulturowych zaowocowało odczuwanym pod koniec XX wieku poczuciem niepewności co do rozwoju cywilizacji oraz końca historii ${ }^{6}$. Zważywszy jednak, że czas kryzysu jest często zaczątkiem nowych zmian, prawdopodobnie tak zdarzyło się w najnowszej historii, co stało się zaprzeczeniem fatalizmu poprzedniej epoki. Zdaniem antropologów obserwujemy jak erozji ulega pesymizm, zamiast narracji o zmierzchu, czy nawet końcu kultury - na rzecz akceptacji jej różnorodności. Powszechnie jest postrzegana zmiana jako rozszerzenie charakterystyki dziedzictwa i możliwości jej ochrony ${ }^{7}$. W dwóch pierwszych dekadach XXI wieku ochrona dziedzictwa rozszerzona została o sferę niematerialną. Cyfrowa rewolucja, podobnie jak narastający kryzys klimatyczny i odbudowa po pandemii uznane zostały głównymi wyzwaniami cywilizacji.

Nowa teoria społeczna zwana „teorią racjonalności komunikacyjnej” zaprzecza dekadencji postmodernistycznej filozofii. Ten system myślowy stworzony przez Jürgena Habermasa, jednego z najwybitniejszych współczesnych filozofów, odpowiada na współczesny kryzys. Habermas tłumaczy potrzeby cywilizacyjne i dyskutuje z innymi myślicielami, jak z Jacques Derridą, o witalnych postawach ludzi, odpowiedziach na terroryzm. Przedstawia podwaliny nowej racjonalności społecznej i rozwoju instytucji. W systemie tym komunikacja i informacja są motorami zmian i ich upowszechnienia, dodatkowo wzmocnionego przez internet. Podobnie rodząca się teoria konserwacji najnowszej spuścizny oparta jest na międzynarodowym procesie porozumienia o otwartym charakterze, także obejmuje pochodzące $\mathrm{z}$ różnorodnych źródeł dziedzictwo, które jest wytworem wielu przenikających się wzajemnie kultur, które przez wieki przyczyniły się do jego rozwoju?.

${ }^{5}$ Bauman Z., Liquid Modernity, Cambridge: Polity Press, 2000. Wydanie polskie: Ptynna nowoczesność, Tomasz Kunz (tłum.). Kraków: Wydawnictwo Literackie, 2006.

${ }^{6}$ W książce mającej rekordy nakładów na całym świecie, pt. „Koniec historii i ostatni człowiek” Francisa Fukuyamy (1997) intelektualne prowokacje miały źródło w kryzysie politycznym i krytyce globalizmu. ${ }^{7}$ Appadurai A., Nowoczesność bez granic. Kulturowe wymiary globalizacji, Kraków: Wyd. Universitas, 2005.

${ }^{8}$ Habermas J., Teoria działania komunikacyjnego. Racjonalność działania a racjonalność społeczna, PWN, t.I., Warszawa 1999, s. 618

9 Santabárbara Morera C.,Conservation of contemporary art: a challenge for the theory of critic restoration?, [w:] Conservando el pasado, proyectando el futuro, tendencias en la restauración monumental en el siglo XXI, Institucíon Fernando el Católico, Zaragoza 2013. 


\section{Rozszerzone rozpoznanie dziedzictwa - teoria i praktyka}

Konfrontacja ze zmianami ukazuje wspólnotę i rozbieżności między traktowaniem dyscyplin tradycyjnych sztuki i nowoczesnych oraz współczesnych, a także dobrami kultury innego rodzaju, jak zabytki techniki. Pierwszoplanowe znaczenie ma całościowe poznanie cech spuścizny. To wyniki rozszerzonego badania dziedzictwa sztuk wizualnych mają nie tylko wyjściowe, ale i kluczowe znaczenie dla procesu ochrony i konserwacji. Ich cechą jest transdyscyplinarność o korzeniach badań konserwatorskich z użyciem badań pomocniczych. Stanowi to obecnie niezbędnik każdego profesjonalisty konserwatora, który w zakresie badań dokumentacyjnych najbliżej poznaje cechy obiektu. Profesjonalnie wykształcony konserwator winien być orkiestratorem badań - tak w zakresie humanistycznym, jak i na polu nauk przyrodniczych. Znaczenie ma przede wszystkim odpowiedni dobór pytań badawczych wynikający ze znajomości obiektu, kontekstu jego powstania i wyników jego wstępnych badań. Następny krok to wybór zastosowania odpowiednich metod analityki instrumentalnej, a następnie zsumowanie wiedzy o obiekcie. Powszechnym błędem jest ograniczenie identyfikacji do wykonywania przypadkowo dobranych badań, pod hasłami nieadekwatnymi do rzetelnej, pełnej wiedzy o obiekcie. Może świadczyć o niekompetencji inwestorów dobór ekspertów,np. w zakresie architektury wedle kryterium ich przydatności do celów developerskich, lub z klucza 'technicznej historii sztuki' (jako urozmaicenia studiów humanistycznych), etc. W stosunku do ochrony dziedzictwa XX wieku prawidłowych identyfikacji dokonujemy według szerokiej definicji sztuki i innych obiektów, np. zabytków techniki, etnograficznych i in. Alternatywna definicja sztuki pojawiła się stosunkowo wcześnie w opisie Władysława Tatarkiewicza:

Sztuka jest odtwarzaniem rzeczy, bądź konstruowaniem form, bądź wyrażaniem przeżyć - jeśli wytwór tego odtwarzania, konstruowania, wyrażania jest zdolny zachwycać, bądź wzruszać, bądź wstrzasaći ${ }^{10}$.

Ta nad wyraz aktualna definicja sztuki otwarty charakter, ujęta jest przez doskonały skrót myślowy, zgodny z najnowszą definicją filozoficzną mimo upływu pół wieku ${ }^{11}$. Implikuje otwarte, rozszerzone rozumienie dziedzictwa sztuki, które wymaga analizy. Jest zależne od różnych aspektów istnienia dzieła, jak ontologiczny (istnienie), semiotyczny (znaczenie), aksjologiczny (wartości), o czym dalej. Dotyczy sztuki o różnych korzeniach, w tym tradycyjnej o charakterze autograficznym, jak architektura, malarstwo, rzeźba itd. Zmiany wprowadza ochrona sztuki o innej specyfice, hybrydowej, tzw. Gesamtkunstwerk, korespondencji sztuk, sztuki o charakterze allograficznym. Sztuka nowoczesna i współczesna traktowane są jako podstawy do odtworzenia,

${ }^{10}$ Tatarkiewicz W., Dzieje Sześciu Pojęć, Warszawa: PWN, 1975, s. 52

${ }^{11}$ https://plato.stanford.edu/entries/art-definition/, dostęp 5.01.2022. 
podobnie jak performans, czy muzyka ${ }^{12}$. Dla myślących analitycznie konserwatorów nie można uniknąć problemu ochrony dziedzictwa nowego zakresu sztuki, jak i spuścizny technicznej. Andrzej Tomaszewski tak opisał konieczność zachowania otwartej postawy poznawczej:

Konserwacja to nie religia i nie może opierać się na dogmatach. Tak samo żadna teoria nie jest stworzona po to, by obowiazywała po wsze czasy. Zawsze jednak trzeba uważnie obserwować świat wokół nas, poddajac go intelektualnej analizie i wyciagając $z$ niej inteligentne wnioski dotyczące teraźniejszości i przyszłości. Nie ma alternatywy - musimy nieustająco myśleć i uczyć się

Zobowiązujący do ochrony szeroki horyzont dziedzictwa przedstawił już przed laty Jan Pruszyński:

$w$ istocie wszystko, co nas otacza, jest dziedzictwem przeszłości, od przedmiotów materialnych po zjawiska obyczajowe, od religii i tradycji po język, literaturę i muzykę (...) od związków z przeszłościa zależy świadome kształtowanie teraźniejszości i przyszłości $i^{14}$.

Wynikają stąd wnioski o konieczności szerszej interpretacji dziedzictwa bez jego uprzedmiotowienia. Na temat związków materialności i niematerialności dziedzictwa dobitnie i skrótowo wyraziła pogląd antropolożka Laurajane Smith stwierdzając: „nie ma takiej 'rzeczy' jak dziedzictwo"15. Do meritum zagadnienia prowadzi stwierdzenie Joela Taylora:

dziedzictwo nie jest przedmiotem ani samym materiałem, ale $p r z y c z$ y $n a, z$ powodu której obiekt jest zachowywany ${ }^{16}$.

Można argumentować, że materia jest ucieleśnieniem i nośnikiem wartości pozamaterialnych, w tym idei, intencji twórców.

${ }^{12}$ Goodman N., The Language of Arts. An approach to the theory of symbols, Hackett Publishing Company, 1976. O architekturze jak mix-przykładzie traktuje artykuł: Werning Remei Capdevilla, Nelson Goodman's Autographic-Allographic Distinction in Architecture: The Case of Mies van der Rohe's Barcelona Pavilion, From Logic to Art, Themes from Nelson Goodman, (eds. Gerhard Ernst et al.), De Gruyter, Ontos Verlag 2009, 269-292; https://www.degruyter.com/view/book/978311032719 9/10.1515/9783110327199.269.xml, dostęp 30.12.2021.

${ }^{13}$ Tomaszewski A., Przyszłość konserwacji jako dyscypliny i jej teoria, [w:] (red.) Murzyn, M., Purchla.J., Dziedzictwo Kulturowe w XXI wieku, Szanse i Wyzwania(Cultural Hertage in the 21st Century, Opportunitirs and Challenges), MCK Kraków, 2007, ss. 169-170.

${ }^{14}$ Pruszyński J., Dziedzictwo kultury Polski. Jego straty i ochrona prawna, t. 1, Kraków 2001, ss. 23-24.

${ }^{15}$ Smith L., Uses of Heritage, Routledge, London 2006, s. 6.

${ }^{16}$ Taylor J., Embodiment unbound: Moving beyond divisions in the understanding and practice of heritage conservation, Studies in Conservation, 2015,nr 60 (1),ss. 65-77 


\section{Podejście paradygmatyczne w nowej teorii konserwatorskiej}

Ze współczesnych zmian kulturowych wynikają nowe pojęcia teoretyczne i wprowadzenie paradygmatów teorii konserwatorskiej ${ }^{17}$.Wymaga to nowych założeń naukowo-konserwatorskich isystematyki postępowania z respektowaniem problematyki ratowania różnorodnego dziedzictwa sztuk wizualnych ${ }^{18}$. Wiadomo, że meandry zachowania fenomenu sztuk wizualnych istniały od ich zarania do współczesności, gdyż to naturalna kolej rzeczy, stąd w XXI wieku ochrona dziedzictwa sztuk wizualnych może być sytuowana w różnych podstawowych paradygmatach ${ }^{19}$ :

- naukowo-konserwatorskim,

- dokumentacyjnym; 'konserwacja poprzez dokumentację,

- procesualnym,

- performatywnym,

- eschatologicznym (śmierć).

Istotny jest aspekt etnograficzny o dużym ładunku społecznym, behawioralny, psychologiczny i inne. Wymaga to oparcia diagnozy konserwatorskiej na wynikach transdyscyplinarnych badań dziedzictwa i dopuszczenia dalszej indywidualizacji charakteru ochrony danego utworu. W realizacji misji „chronić i przekazywać” zachowanie wielu nietradycyjnych dzieł sztuki współczesnej polega na ich dokładnej dokumentacji, magazynowaniu składowych, prezentacji i re-instalacji oraz rekonstrukcji podczas prezentacji. Instalacje, dzieła procesualne, a także dzieła performatywne nie odgrywają nadanej mu roli, gdy nie następuje fenomen zaistnienia sztuki. Magazynujemy jedynie części składowe obiektu, a nie dzieło sztuki będące w tym przypadku do odtworzenia ${ }^{20}$. Dla muzealników rośnie znaczenie specyfiki „konserwacji przez dokumentacje”, często zawierającą autoryzowany wywiad $\mathrm{z}$ artystą, która może być punktem wyjścia do wiarygodnego odtworzenia. Także definiują rekonstrukcje powiązania w zakresie systemu wartościowania w dwóch kategoriach. Patrz ANEKS. Wiarygodności cyfrowego dziedzictwa, obrazowania cyfrowego i sztuki wirtualnej określa tzw. Karta londyńska ${ }^{21}$, czego przykładem jest

${ }^{17}$ Szmelter I., Paradygmat Teorii I Praktyki Konserwatorskiej W Odniesieniu Do Sztuki Nowoczesnej, [w:] Wspótczesne Problemy Teorii Konserwatorskiej w Polsce, red. B.Szmygin, Międzynarodowa Rada Ochrony Zabytków ICOMOS, Politechnika Lubelska,Warszawa - Lublin 2008, ss. 133-144.

${ }^{18}$ Llamas-Pacheco R., Some Theory for the Conservation of Contemporary Art, Studies in Conservation, 2020, 65:8, ss. 487-498.

${ }^{19}$ Szmelter I., O fenomenie sztuk wizualnych..., op.cit., ss. 91-160.

${ }^{20}$ Van de Vall R., Hoelling H., Scholte T., Stiegter S., Reflection on a Biographical Approach to Contemporary Art Conservation, Lizbona 2011.

${ }^{21}$ Bentkowska-Kafel A., Historyczna wiarygodność zabytku wirtualnego. Uwagi na marginesie postulatów Karty Londyńskiej, [w:] Nowoczesne metody gromadzenia i udostęniania wiedzy o zabytkach, red. Seidel-Grzesińska A., Stanicka-Brzezicka K., Wrocław 2008, ss. 35-47. 
zastosowanie $\mathrm{w}$ wirtualnym projektowaniu architektonicznym ${ }^{22}$. Podejście paradygmatyczne stanowi teoretyczną adaptację do wielu nietypowych cech obiektu i proponowanych przez autorkę dwóch głównych kategorii analizy wartościującej.

\section{Studia nietypowych przypadków w rozszerzonym obszarze dziedzictwa.}

Paradygmatyczny charakter ma ochrona konserwacji wielu dzieł sztuki nowoczesnej i współczesnej pro domo sua - pioniersko prowadzona od lat 80-tych ub. w warszawskiej ASP, obecna w literaturze międzynarodowej, łącząc naukę, przemyślenia teoretyczne i sztukę ${ }^{23}$. W tym ponad stu pięćdziesiąt utworów sztuki nowoczesnej awangardowego dziedzictwa Aliny Szapocznikow (z lat 1956-1973) dokonana przez piszącą te słowa ${ }^{24}$. Kompleksowy charakter dziedzictwa, zarówno sztuki autograficznej, jak i dziedzictwa sztuki allograficznej, w tym konceptualnego i performatywnego przedstawiała ochrona cennego dorobku Tadeusza Kantora i wielu innych twórców. Opracowania teoretyczne i studia przypadków ochrony nietypowego dziedzictwa prezentowane są $\mathrm{w}$ wielu projektach krajowych i międzynarodowych od połowy lat osiemdziesiątych ub. wieku do dzisiaj. Ostatnio, w 2021 roku, poświęcone były zachowaniu sztuki w przestrzeni publicznej, zarówno street art o charakterze amatorskim, jak i muralom zamawianym w wyniku nowych inicjatyw kulturalnych w przestrzeni miejskiej ${ }^{25}$.

$\mathrm{W}$ ujęciu paradygmatycznym teorii konserwacji wachlarz od rozszerzonej roli dokumentacji, aktywnej konserwacji i zachowania obejmuje procesy konserwacji-restauracji-rekonstrukcji, odtworzenia, emulacji, gdy te interwencje są uzasadnione. Rozważane są uzasadnione entropią

${ }^{22}$ Koszewski K., Franczuk J., Argasiński K., Wirtualne modele dziedzictwa architektonicznego a działalność konserwatorska/Architectural Heritage Virtual Models in Conservation Practice, Wiadomości Konserwatorskie. 2021;(68S), ss. 17-25.

${ }^{23}$ Theory and practice in the conservation of modern and contemporary art.Reflections on the roots and the perspectives (2010), ed. Schädler-Saub U., Weyer A., Hildesheim, Archetype, London.

${ }^{24}$ Szmelter I., Kurkowska J., The Innovative Approaches Of Complex Care For Alina Szapocznikow Legacy with Case Studies. New Insight Into Preservation Theory Of Contemporary Art, [w:] Science and Art. The Contemporary Painted Surface, Royal Society of Chemistry, RSC Cambridge, 2019, rozdział 5, ss. 108-149.

${ }^{25}$ Urban art: i co dalej-zagadnienia ochrony sztuki wspótczesnej, red. I. Szmelter, (autorzy: Iwona Szmelter, Żaneta Gwardzińska, Tytus Sawicki, Anna Kowalik)"- to alert dla zachowania sztuki w przestrzeni miejskiej. Opublikowana w wolnym dostępie (open access) wj.pol. https://wydawnictwo. asp.waw.pl/publikacja/urbanart-i-co-dalej-zagadnienia-ochrony-sztuki-wspolczesnej/,oraz angielskim, https:/wydawnictwo.asp.waw.pl/publikacja/urban-art-and-what-next-the-issues-ofpreservation-of-contemporary-art/. Ten nowatorski projekt mający na celu ustalenie zasad ochrony sztuki miejskiej o nazwie Conservation of Art in Public Spaces, akronim CAPuS (2018-2021), zebrał szesnastu partnerów, z uczelni, firm i instytucji z Włoch, Polski, Niemiec, Chorwacji i Hiszpanii oraz jeden z USA. Realizowany był w ramach "Knowledge alliances" Erasmus +" i sfinansowany przez Komisję Europejską. 
metody ochrony dzieł efemerycznych na drodze 'śmierci dzieła' i jego 'konserwacji poprzez dokumentacje. Zawsze jednak priorytetem jest niezbędne oparcie na rozpoznaniu charakteru i specyfiki dzieł, dokonanie analizy wartościującej, a błędem jest podejście woluntarystyczne. Odpowiedzią na wyzwania współczesnego obrazu dziedzictwa powołano nowe kierunki kształcenia na warszawskim Wydziale Konserwacji i Restauracji Dzieł Sztuki w Akademii Sztuk Pięknych. Tak zakrojone przyszłościowo kształcenie powinno być zgrane z analizą wartościującą dziedzictwo sztuk wizualnych i przydatne w reformowanych instytucjach kultury.

\section{Rozszerzona analiza wartościująca}

W proponowanej analizie wartościującej sztuk wizualnych, dawnych i współczesnych, oraz szeroko rozumianych dóbr kultury, szerzej niż w zabytkoznawczej analizie, przedstawiony jest przez autorkę system wartościowania w dwóch wzajemnie uzupełniających się kryteriach: artystyczno-estetycznym, a także społeczno-ekonomicznym. Z licznymi podgrupami, które wspólnie prowadzą do zrównoważonego rozwoju. System tak zaplanowany uwzględnia propozycje wielu teoretyków i rozwiązania autorki, które mają charakter badawczy i stosowany. Zachowanie tak szeroko rozumianego dziedzictwa człowieka wymaga dokonania całościowej analizy wartościującej i hierarchizacji składowych wartości dziedzictwa. Dopiero potem można je całościowo i spójnie prezentować. Podążając za kategoriami i podgrupami szukamy odpowiedzi na pytanie, jakie są zasadnicze elementy utworu/dzieła/obiektu, jak wzajemnie się uzupełniają. Istotna jest odkryta w analizie wartościującej hierarchia, które je konstytuuje, zarówno w sferze materialnej, jak i niematerialnej oraz cyfrowej. Ich określenie i ewentualna kolejność legitymizują pełne rozpoznanie wartości dzieła, tak by podjęta diagnozę można było oprzeć na wynikach analizy wartościującej. Spójność dzieła to suma jego właściwości, zarówno materialnych, jak i niematerialnych, także suma wartości dawnych i nowatorskich utworów. Te ostatnie mogą wymagać otwarcia na paradygmaty nowej teorii konserwacji. W każdym praktycznym przypadku konserwacji zostanie określone, w jakim paradygmacie, jednym lub wielu, należy uwzględnić utwór/dzieło sztuki/obiekt pod względem jego autentyczności $\mathrm{i}$ istoty, prawdy o sztuce ${ }^{26}$. Postępujemy w ten nowatorski sposób, by „chronić i przekazywać” dziedzictwo, zgodnie z najlepszą profesjonalną wiedzą i etyką zawodową, zasadami ustalonymi dla danego dzieła, osobno dla tradycyjnego, jak i współczesnego w poniżej odpowiednio dobranym scenariuszu. Patrz - ANEKS.

\section{Filary rozszerzonego postępowania konserwatorskiego}

Dyskusji i argumentacji wymaga zgoda w praktyce konserwatorskiej na odstępstwa od zasad dla tradycyjnych dyscyplin. Istotne są rozbieżności w traktowaniu sztuki dawnej utrzymanej w dyscyplinach, a nowych zjawisk sztuk współczesnych. W pierwszym przypadku spuścizny z kręgu kultury materialnej (np. w tradycyjnych instytucjach, będących w kręgu oddziaływania

${ }^{26}$ Llamas-Pacheco R., Some Theory for the Conservation of Contemporary Art, op.cit., s. 490. 
tradycyjnej kultury zachodnioeuropejskiej) stosujemy tradycyjną taktykę ochrony i konserwacjirestauracji $\mathrm{z}$ najlepszą wiedzą i etyką zawodową. respektując podstawowe syntetycznie zestawione przez Bogumiłę Roubęę. Biorąc pod uwagę rozbieżności w traktowaniu sztuki dawnej i współczesnej dokonać trzeba niezbędnych modyfikacji zasad zachowania o nowe drogi interpretacyjne dotyczące materialności/niematerialności dziedzictwa, paradygmatyzacji, czy jego cyfryzacji. To nie jest kwestia wyboru jednej drogi, a raczej połączenia ich wielości, wspartej rieglowskim relatywizmem historycznym. Sztuka i jej dziedzictwo istniejące materialnie są wszak od wieków ucieleśnieniem idei jej twórców zawierającym bogaty kontekst duchowy swojej epoki. Filary postępowania konserwatorskiego stanowią łącznie ramę ochrony dziedzictwa sztuk wizualnych, które autorka określa następująco:

- PRIMUM NON NOCERE, postępowanie zgodne naczelną zasadą etyczną zgodnie z maksymą hipokratejską, by przede wszystkim nie szkodzić,

- prowadzenie badań identyfikacyjnych i wielodyscyplinarnych studiów przed diagnozą i sformułowaniem projektu konserwatorskiego, wszystkie zagadnienia przedstawione są w dokumentacji przed podjęciem decyzji.

- rozszerzona rola dokumentacji jako wyniku badania: wykorzystujący nowe metody rejestracji i archiwizacji, podkreślając, że właściwe rozpoznanie dzieła i jego dokumentacja są wyjściowymi elementami ochrony,

- zachowanie minimalnej niezbędnej ingerencji, ale nie jako sztywnej zasady, ale dostosowane dla specyfiki utworu/dzieła/obiektu dla danego paradygmatu teorii konserwatorskiej,

- maksymalnego poszanowania dla oryginalnej jego substancji i wszystkich jego wartości,

- postępowanie dla zachowania potencjalnej jedności utworu/dzieła/obiektu i jego integralności,

- możliwą odwracalnością metod i materiałów(która nie zawsze jest realna w praktyce),

- czytelności i odróżnialności ingerencji, jeśli nie znakiem konserwatorskim, to w dokumentacji oraz w komunikacie dla odbiorców

- wykonywania ingerencji konserwatorskiej i dokumentacji prac zgodnie z najwyższą wiedzą i na najwyższym poziomie. To wymaga rozszerzenia i aktualizacji profesjonalnej wiedzy konserwatorskiej. Nie ma miejsca na amatorstwo, a przystępując do badań nie możemy kierować się rutyną, lub powtarzalnością zagadnień.

- partycypacji społecznej na etapach identyfikacji dzieła i jego stanu zachowania, diagnozy i projektu konserwatorskiego, niezbędne jest upowszechnienie informacji, by obiekt był zrozumiały dla odbiorcy.

${ }^{27}$ Rouba B., Proces ochrony dóbr kultury - pojęcia, terminologia, [w:] Ars longa - vita brevis - tradycyjne i nowoczesne metody badania dzieł sztuki, red. J. Flik, Torun 2003, ss. 349-379. 


\section{Poparcie dla budowania kapitału kulturowego}

Udział społeczny jest modus vivendi dla dopełnienia sensu ochrony dziedzictwa, wymaga uczestnictwa aktorów sieci w kulturoznawczych procesach $(\text { ATN })^{28}$, interesariuszy. Zawsze reprezentacja kapitału kulturowego jest elementarną składową ochrony dziedzictwa kultury.

Oznacza sposób funkcjonowania przez mosty porozumienia. Pożądane są zmiany w tym kierunku popandemicznej re-organizacji życia, jego estetyzacji i ekologii, dobrostanu społecznoekonomicznego. Nabierają znaczenia oddolne inicjatywy, rośnie udział mieszkańców w planowaniu przestrzennym przy narastającej dysfunkcji instytucji, zbyt sztywnych wobec zachodzących zmian.

\section{Konkluzja}

Opracowanie dotyczy aktualizacji teorii konserwatorskiej z niezbędnym uwzględnieniem rozszerzonego obszaru dziedzictwa sztuk wizualnych, od ich zarania aż do współczesności, zawierającej elementy kultury materialnej i niematerialnej oraz dziedzictwa cyfrowego. Wobec rozszerzenia rozumienia dziedzictwa stają wszyscy autorzy, którzy reprezentują wiele specjalności w obrębie ochrony i konserwacji zabytków. Od zabytków architektury, urbanizmu, poprzez zagadnienia pejzażu kulturowego, zachowanie „genius loci”, aż do zagadnień związanych z konserwacją zabytków ruchomych oraz współczesnej sztuki autograficznej i allograficznej.

To trudne zadanie, niczym porządki w stajni Augiasza, ale mimo braku herkulesowych sił potrzebna jest zainicjowanie zmian i krok po kroku ich wprowadzenie. Wdrożenie nowej teorii implikuje odpowiednie filary praktyki konserwatorskiej. Oparte są mi.in. na paradygmatach współczesnej teorii, niezbędnych wobec nieprzystawalności teorii do obecnego, rozszerzonego obszaru dziedzictwa. Powszechnie znany i stosowany jest paradygmat naukowo-konserwatorski. Warunkiem jest oparcie na konserwatorskiej dokumentacji dzieł umożliwiającej odpowiedzialne wykorzystanie dokumentacji $\mathrm{w}$ różnych zakresach. Jednocześnie funkcjonuje paradygmat „konserwacji poprzez dokumentację" w odniesieniu do sztuki efemerycznej, o nowym, rozszerzonym zakresie, wywodzący się z podstaw naukowej dokumentacji konserwatorskiej. Dokumentacja staje się podstawą dla wszystkich procesów ochrony dziedzictwa. Także obecna w realizacji paradygmatu procesualnego, który wyraża zmiany ostatnich dwustu lat. W pracy kinetycznej ważniejsza jest jej idea i funkcja niż materia, która w celu przywrócenia kinetyki obiektu może być uzupełniona lub substytuowana. W dziełach cyfrowych akceptowany jest ich przekaz na nowych nośnikach. Rośnie znaczenie wirtualnego projektowania architektonicznego. Uwagi wymaga paradygmat performatywny towarzyszący sztuce o charakterze allograficznym i jej zachowaniu przez odtwarzanie i emulację. To oznacza, że sztuka z elementami performansu może powtarzana, bez utraty swojej autentyczności, nie traktowanej li tylko materialnie.

${ }^{28}$ Abriszewski K., Poznanie, zbiorowość, polityka. Analiza teorii aktora-sieci Bruno Latoura, Kraków, Towarzystwo Autorów i Wydawców Prac Naukowych, "Universitas", 2008. 
Efektem zmian $\mathrm{w}$ teorii konserwacji winno być uszanowanie różnorodności charakteru dziedzictwa. Dotyczy sytuacji, w której funkcjonuje i przedstawia swe wartości każdy utwór człowieka - budynek, pejzaż kulturowy, zabytki techniki, dzieła sztuki etc. i jest następstwem szerokiego rozumienia dziedzictwa jako zasobów kultury materialnej i niematerialnej oraz cyfrowej. W myśl obecnego rozumienia dziedzictwo nie jest już tylko przedmiotem, czy chronionym miejscem, ani zasobem kultury materialnej. Staje się także pamięcią lub odniesieniem kulturowym, z ważną przyczyną ochrony, ucieleśnieniem idei towarzyszących rozwojowi człowieka. Za tym rozumieniem teoria kreśli coraz szersze scenariusze oparte na proponowanym systemie analizy wartościującej w uzupełniających się kategoriach i podgrupach: kulturalno-historycznym z społeczno-ekoomicznym(patrz ANEKS). Współczesna ochrona dziedzictwa kontekstualizowana jest $\mathrm{w}$ odniesieniu do kilku wymiarów zrównoważonego rozwoju: środowiska, rozwoju samej kultury, tożsamości w ujęciu antropologicznym, ekonomii oraz dobrostanu społecznego.

Iwona Szmelter. ANEKS.

\section{System analizy wartościującej w kategoriach wzajem zależnych:}

Na opracowanie systemu wartościowania dziedzictwa sztuk wizualnych złożyły się wcześniejsze interpretacje - od Aloisa Riegla, przez Waltera Frodla, Cesare Brandiego, zespółu badaczy Getty Conservation Institute z Eriką Avrami oraz Martą della Tore, przez autorkę tych słów i innych autorów. Obecna propozycja ma charakter podsumowujący opisy i je rozszerzający. Autorka przedstawia dwie generalne kategorie analizy wartościującej z licznymi, istotnymi podgrupami w sposób sugerujący ich osobne lub całościowe traktowanie. Towarzyszy temu założenie, że dziedzictwo kultury generalnie zawiera wartości autoteliczne - jest już wartością z powodu swego istnienia.

I KATEGORIA PODSTAWOWA TO WARTOŚCI KULTURALNO-HISTORYCZNE, z jednej strony opisane od strony wartości humanistycznych, które do niedawna dominowały w analizie, w tym artystyczne, estetyczne i inne.

II KATEGORIA TO WARTOŚCI SPOŁECZNO-EKONOMICZNE, które z drugiej strony przedstawiają uwarunkowania społeczne, partycypację odbiorców, udział aktorów sieci (ATN), w tym interesariuszy spoza kręgu konserwatorskiego, mające wpływ na praktyczne i ekonomiczne możliwości finansowania i ochrony wartości dziedzictwa.

Proponowana jest łączna ANALIZA WARTOŚCIUJĄCA biorąca pod uwagę wzajemne oddziaływanie składowych. Opis ma otwarty charakter, niezależnie od faktu, że współczesna zmiana statusu ontologicznego dziedzictwa przenosi uwagę na potrzeby społeczeństwa. 


\section{WARTOŚCI KULTURALNO-HISTORYCZNE Wartość artystyczna dziedzictwa: \\ forma dzieła, obiektu, budynku, zespołu, utworu (jakość i oddziaływanie). Obok uznanych wartości istnieje względna wartość artystyczna - zgodność z współczesną wolą twórczą ; implikuje ostrożność $\mathrm{w}$ arbitralnym osądzie, schemacie typologii stylu i zapobiega zastosowania nieadekwatnych terminów dla utworów. Wartość artystyczna ujawnia się odbiorcy w wyniku procesu poznania dziedzictwa.}

\section{Wartość estetyczna:}

filozoficznie przedstawia aspekty percepcji zmysłowej; atrybut oceniany $\mathrm{z}$ perspektywy czasu i miejsca powstania obiektu; w tym porównawcza unikatowość estetyczna; wartość dawności; spójność i integralność dzieł, spełnia oczekiwanie piękna lub innych aspektów (atrakcyjność wizualna, malowniczość, unikat, dramat i in.)

\section{Wartość estetyczna:}

filozoficznie przedstawia aspekty percepcji zmysłowej; atrybut oceniany $\mathrm{z}$ perspektywy czasu i miejsca powstania obiektu; w tym porównawcza unikatowość estetyczna; wartość dawności; spójność i integralność dzieł, spełnia oczekiwanie piękna lub innych aspektów (atrakcyjność wizualna, malowniczość, unikat, dramat $\mathrm{i}$ in.)

\section{Wartość historyczna:}

przedstawia historie idei i ludzi (pamięć ludzka) i ich dorobku, źródło wiedzy o minionym czasie; ciągłość historyczna; wartość misyjna (przekaz „przeszłości dla przyszłości”); tożsamość miejsca, osób, zdarzeń, unikatu; narodowa wartość, historyczny charakter stref i pejzażu historycznego; wartość pamiątkowa (miejsce pamięci) i wizerunku.

\section{Wartość identyfikacji z kulturą:}

rola dziedzictwa kulturowego w kreacji znaków, symboli tożsamości społeczeństwa, zarówno w skali globalnej i regionalnej, identyfikacja jednostki w jej rozwoju osobistym; relacyjna jakość bytu; pamięć kulturowa; znawstwo i erudycja kult.; ocena oryginalności i autentyzmu w całej różnorodności(materiałów, bogactwa idei).

\section{WARTOŚCI SPOŁECZNO-EKONOMICZNE}

\section{Wartość edukacyjna:}

dziedzictwo jako dowód ciągłości rozwoju i potrzeb zapewnienia istnienia człowieka, budowa poczucia społecznego dobrostanu, budowanie tożsamości, znajomość cech różnych kręgów kulturowych. Dla wiedzy o historii kultury oraz popularyzacji istnieje potrzeba wprowadzenia $\mathrm{w}$ zarysie generalnych podziałów w zakresie stylu, przy respekcie dla individuum. Określenie wartości w zakresie znawstwa, koneserstwa, kolekcjonerstwa.

\section{Wartość ekonomiczna dziedzictwa:}

jako źródło dobrostanu społecznego, 'produkt kulturowy' dla turystyki i tzw. przemysłów kreatywnych; wybór modelu turystyki, ekonomiczne ukazanie wyjątkowości, atrakcyjności, unikatu; nowe znaczenie dziedzictwa (materialne, niematerialne, digitalne) w korelacji z zapewnieniem zatrudnienia.

\section{Wartość ekonomiczna dziedzictwa:}

jako źródło dobrostanu społecznego, 'produkt kulturowy' dla turystyki i tzw. przemysłów kreatywnych; wybór modelu turystyki, ekonomiczne ukazanie wyjątkowości, atrakcyjności, unikatu; nowe znaczenie dziedzictwa (materialne, niematerialne, digitalne) w korelacji z zapewnieniem zatrudnienia.

\section{Wartości społeczne:}

dla poznania, wzbogacenia wiedzy dla rozwoju społecznego, wartość zachowania regionalnej i lokalnej specyfiki, wartość informacji dla odtworzeń historycznych wydarzeń, bitew i in..; waloryzację dziedzictwa w otoczeniu człowieka; weryfikacje/ lub rozrzeszenie zbioru zabytków (i prawodawstwa) o współczesne dobra kultury (zachowanie i przekaz).

\section{Wartości funkcjonalne:}

użytkowość, zachowanie dziedzictwa jako wiarygodnego dokumentu działalności człowieka w przeszłości; w dawnych kontekstach społecznych; funkcje w kategoriach antropologicznych; pamięć społeczna; eksponowanie pomysłu, funkcji przez zachowanie techniki wykonania, przy dopuszczalnej substytucji materiałów i in. 


Wartość naukowa:
Odkryć, heurystyki w twórczej myśli, technik
i technologii; hierarchii składowych dziedzictwa;
implikacje identyfikowania związków dziedzictwa
kultury materialnej, niematerialnej, cyfrowej.
Znaczenie wyników transdyscyplinarnych badań
konserwatorskich dla wartościowania, znaczenie
odkryć i nowych teorii; wysoki poziom dyskursu
intelektualnego.

Wartość autentyzmu (materii $i w$ calym bogactwie i różnorodności):

holizm we współczesnym rozumieniu całego bogactwa znaczenia autentyzmu - materii/ idei; wiarygodność dziedzictwa na polu dziedzictwa materialnego, niematerialnego, digitalnego; desygnaty materialne w kulturze; zmienność nośników cyfrowych. Spójność i integralność dziedzictwa.

\section{Wartości emocjonalne:}

wywołujące wrażenia emocjonalne przez sztukę, przez obiekt, odczuwanie empatii wobec dawności, historii, wartości w czasie i przestrzeni (genius loci), humanistyczne podstawy pamięci; znaczenie przekazu w prowokowaniu empatii i zrozumienia ciągłości kultury, wychowanie $\mathrm{w}$ poszanowaniu tradycji i wartości jej świadectw dziedzictwa; sztuka jako gra, symbol i święto; koło hermeneutyczne dziedzictwa, wspólnota będąca przestrzenią życia, dialogu, kultury.

\section{Wartości dokumentalne:}

wartość autoteliczna jako dokumentu działalności człowieka „W przeszłości i w teraźniejszości dla przyszłości”; rola dowodu w kompleksowym systemie edukacji na rzecz dziedzictwa; wartość archiwalna dla zachowania kultury materialnej i niematerialnej, dowodu wartości regionalnej, idei politycznych, techniki, (pomysł i wykonanie); Zastosowania w wirtualnym projektowaniu. dokumentacjach w konserwacji.

\section{Wartość integralności:}

oznacza kompletność/spoistość w odniesieniu zarówno do wartości dzieła sztuki, architektury, zespołu krajobrazowego i jego kontekstu, aspektu historycznego; wskazanie w jakim stopniu reprezentuje dany okres lub temat.

\section{Wartości poznawcze:}

dla zwiększenia udziału i satysfakcji społeczeństwa w relacjach z dziedzictwem, partycypacji społecznej, kształtowania 'społeczeństwa refleksyjnego'; rozpoznanie różnych aspektów stylistyki dzieł, symboli, znaków, ikonografii w sztuce; społecznie przydatne powiązania z ogólną wiedzą; w kontekście historycznego krajobrazu miejskiego, czasoprzestrzenne relacje.

\section{Wartość 'produktu kulturowego':}

budowanie tożsamości przez wartość znaku i symbolu, wartość regionalną, polityczną, wartość dla grup mniejszościowych, wirtualne projektowanie, odtworzenia sytuacyjne, przekaz turystyki kulturowej; zdolność do reprodukcji (oddziaływanie masowe), podejście partycypacyjne w użytkowaniu dziedzictwa.

\section{Wartości społeczno-operacyjne:}

potencjalna wartość dla przyszłej eksploatacji i generowania wartości o historycznych źródłach; wskazanie istotnej zabezpieczenia dla przyszłości współczesnych dóbr kultury i roli współczesnego i przyszłego dziedzictwa; przydatność dla twórcy i odbiorcy we wzajemnej aktywności; trend centralizowania magazynów muzealnych zabezpieczenie fizycznej pamięci dziedzictwa); skuteczne zarządzanie zasobami dziedzictwa.

\section{Wartości społeczno-administracyjne:}

rozszerzenie roli dokumentacji dla jej zastosowania w przyszłości, cyfrowa inwentaryzacja, cyfrowe dziedzictwo, modelowanie obiektowe; przydatność dla integrującej mocy sztuki; wartości dla organizowania form życia społecznego dla różnych generacji i grup, edukacyjnych(od przedszkolaków do seniorów), do celów relaksacyjnych, rehabilitacyjnych; odniesieniu do efemeryczności „Konserwacja przez dokumentację”.

\section{Wartość znaku:}

wartość ekonomiczna znaku towarowego (brand name), budowania wizerunku, np. budynku, instytucji, osoby, produktu, miejscowości, regionu; sieć skojarzeń przez związek z wydarzeniem historycznym, tradycją lub postacią. 


\begin{tabular}{|c|c|}
\hline $\begin{array}{l}\text { Wartości kreatywności i nowatorstwa: } \\
\text { kreatywne dzieła ludzkiego geniuszu twórczego } \\
\text { o artystycznym lub technicznym charakterze; } \\
\text { ewenement jako wyróżnienie dzieła na linii czasu, } \\
\text { wiążąc je z kontekstem historycznym i innymi } \\
\text { dziełami powstałymi równocześnie; wartość rzadkości, } \\
\text { unikalność, wyjątkowość; nowatorskie projektowanie } \\
\text { w sztuce użytkowej (design); techniki informacyjne. }\end{array}$ & $\begin{array}{l}\text { Wartości funkcjonalne nowości: } \\
\text { nowatorstwo spełniające naturalne ludzkie potrzeby, } \\
\text { przyjemności i zaspokojenie zaciekawienia; wpływ } \\
\text { na kształtowanie potrzeb społecznych, znaczenie } \\
\text { marketingowe produktów; tendencje i moda } \\
\text { w kreowaniu rynku, wartość aktualności i atrakcyjności } \\
\text { dziedzictwa, funkcjonalny postęp we wzornictwie; } \\
\text { możliwość wirtualizacji komunikacji międzyludzkiej. }\end{array}$ \\
\hline $\begin{array}{l}\text { Wartości w przestrzeni społecznej: } \\
\text { położenie obiektu (location), przestrzeń w sensie układu } \\
\text { elementów tworzących formę, plan, oddziaływanie } \\
\text { struktury dzieła wewn. i zewn.na fizyczne otoczenie } \\
\text { obiektu (setting), jako gra w przestrzeni i czasie } \\
\text { (Brandyjska teoria restauracji). }\end{array}$ & $\begin{array}{l}\text { Wartości lokalne rzemiosła: } \\
\text { zachowanie umiejętności rzemieślniczych danej } \\
\text { kultury w danym miejscu i czasie (workmanship), } \\
\text { kontynuacja charakteru otoczenia, związków człowieka } \\
\text { z materiałem, z którego wykonano obiekt w danej epoce } \\
\text { (materials). }\end{array}$ \\
\hline
\end{tabular}

Przedstawiony system analizy wartościującej jest otwartym procesem w ochronie dziedzictwa materialnego, niematerialnego i cyfrowego, szerszym od „zabytkowej analizy wartościującej”. Po raz pierwszy powyższe opracowanie prezentowane było przez autorkę na Inteerim Meeting ICOM-CC, Working Group History and Theory w Kopenhadze w 2013, publikowane w CeROArt w 2014( j.ang. ${ }^{29}$, rozszerzone w publikacji „Sztuka i Dokumentacja” (w j.polskim i abstrakt ang.) w 2016, w Wiadomościach Konserwatorskich SKZ ( w j. polskim i ang.)w 2018 oraz w autorskiej monografii O fenomenie sztuk wizualnych i meandrach ich ochrony. Filozofia $i$ elementy nowej teorii i praktyki konserwacji, Wydawnictwo Naukowe PWN, Warszawa, (w j. polskim w 2020 i ang. w 2021).

${ }^{29}$ Szmelter I., New Values of Cultural Heritage and the Need for a New Paradigm Regarding its Care, CeROArt, http://ceroart.revues.org/3647, start opracowania otwartego na problemy współczesności. 


\section{Bibliografia}

Llamas-Pacheco R., Some Theory for the Conservation of Contemporary Art, Studies in Conservation, 2020.

Santabárbara Morer C., Conservation of contemporary art: a challenge for the theory of critic restoration?, [in:] Conservando el pasado, proyectando el futuro, tendencias en la restauración monumental en el siglo XXI, Institucíon Fernando el Católico, Zaragoza, 2013.

Smith L., Uses of Heritage. Routledge, London, 2006.

Szmelter I., New Values of Cultural Heritage and the Need for a New Paradigm Regarding its Some Theory For The Conservation Of Contemporary Art Care, CeROArt, 2013, http://journals. openedition.org/ceroart/3647.

Szmelter I., Kurkowska J., The Innovative Approaches Of Complex Care For Alina Szapocznikow Legacy with Case Studies. New Insight Into Preservation Theory Of Contemporary Art, [w:] Science and Art. The Contemporary Painted Surface, Royal Society of Chemistry, RSC Cambridge, 2019.

Szmelter I., O fenomenie sztuk wizualnych i meandrach ich ochrony, Filozofia i elementy nowej teorii i praktyki konserwacji, WN PWN, Warszawa, 2020.

Theory and practice in the conservation of modern and contemporary art.Reflections on the roots and the perspectives (2010), ed. Schädler-Saub U., Weyer A., Hildesheim, Archetype, London.

Urban art: i co dalej- zagadnienia ochrony sztuki współczesnej, (2021), red. I. Szmelter, (autorzy Iwona Szmelter, Żaneta Gwardzińska, Tytus Sawicki, Anna Kowalik); open access w j.pol. https://wydawnictwo.asp.waw.pl/publikacja/urbanart-i-co-dalej-zagadnienia-ochrony-sztukiwspolczesnej/,oraz w j. angielskim, https://wydawnictwo.asp.waw.pl/publikacja/urban-art-andwhat-next-the-issues-of-preservation-of-contemporary-art/

Wspótczesne Problemy Teorii Konserwatorskiej w Polsce, red. B. Szmygin, Międzynarodowa Rada Ochrony Zabytków ICOMOS, Politechnika Lubelska, Warszawa - Lublin, 2008. 